\title{
Comparative Analysis of Selected Factors Affecting Heating Costs of Schools in Selected Balkan Countries
}

David Koppitz, Milan Přček ${ }^{2}$, František Ochrana ${ }^{3}$, Michal Plaček $^{4}$

\begin{abstract}
The paper aims to carry out a comparative analysis of heating of school facilities under the administration of municipalities in Macedonia, Moldova and Kosovo and to test the factors that affect the heating costs of school facilities. For a definition of the theoretical fundament parts of the theory of fiscal federalism are used. Subsequently five hypotheses are put forward that are verified using the method of benchmarking. The theoretical conclusions and recommendations may be used for a more effective implementation of public policies within the surveyed countries.
\end{abstract}

Keywords: comparative analysis, municipalities, heating cost

\section{Introduction}

Apart from the available personnel effective running of school facilities also requires corresponding material equipment and sufficient operating resources. In this study we focus on the exploration of resources that are used for heating school facilities.

The study presents results of a comparative analysis of the heating costs of school facilities in three countries that are compared with each other - Macedonia, Moldova and Kosovo. These are costs that are incurred in the contet of running

1 Union of Towns and Municipalities of the Czech Republic, Prague Congress Centre, 5. května (1640/65 Prague Congress Centre), 14021 Praha 4.

2 Private College of Economic Studies in Znojmo, Loucká 21, 66902 Znojmo, Czech Republic.

3 Faculty of Social Sciences, Charles University, Smetanovo nábřeží 995/6, Prague.

4 Private College of Economic Studies in Znojmo, Loucká 21, 66902 Znojmo, Czech Republic. 
school facilities that provide the following levels of education: ISCED 0-ISCED 3 (see Table 1). ${ }^{5}$

Table 1

Characteristics ISCED 0 - ISCED 3

\begin{tabular}{|l|l|l|}
\hline \multicolumn{1}{|c|}{ Level } & Term used within the text & \multicolumn{1}{c|}{ Characteristic } \\
\hline ISCED 0 & Pre-primary education & Education from 3 years of age \\
\hline ISCED 1 & Primary education & First level of primary education \\
\hline ISCED 2 & Lower secondary education & Second level of primary education \\
\hline ISCED 3 & Upper secondary education & $\begin{array}{l}\text { Secondary-school education from 15 (16) } \\
\text { years of age. Follows the completion of } \\
\text { primary education }\end{array}$ \\
\hline
\end{tabular}

Source: OECD (2011). Modified.

The analysis of costs was performed within the project "Transfer of Czech knowledge in support of local government associations of Macedonia, Moldova and Kosovo to strengthen capacities for policy advocacy for improving/establishing fiscal incentives for energy efficiency measures in public schools". This project was supported by the Czech Trust Fund UNDP and implemented by the company MEPCO (a subsidiary of the Association of Towns and Municipalities of the Czech Republic and the Dutch Association), which specifically focuses on a transfer of experience at the municipal level (since 2005) and also on international benchmarking (since 2012). In 2012 a project for Serbian towns was undertaken called "Municipal Benchmarking - waste management and waste water management in Serbia". The outcome of the project was a web application, comparative summary reports and individual reports for each participant, which included a comparison of the situation with other comparable towns. In 2012 and 2013 a project was implemented with the aim of comparing Czech and Georgian towns and transferring good practice (in the spheres of waste management and strategic administration). In 2012 and 2013 a benchmarking project of 3 countries (Macedonia, Moldova and Kosovo) in the sphere of energy management was implemented. The aim of the project was to obtain data on energy consumption related to heating of public schools and using the data analysis to identify the room for improvement and to secure savings in the realm of energy management of schools. The results of this survey make up the contents of this paper.

The article aims to carry out a comparative analysis of heating of school facilities administered by municipalities in Macedonia, Moldova and Kosovo and to test the factors that influence heating costs of school facilities. No similar study comparing the surveyed countries has been processed so far. However, there are practical

5 Classification ISCED ((International Standard Classification of Education) uses the OECD methodology which was revised in 1997. For a detailed classification, see OECD (2011). 
studies focused on other countries with a related subject matter. These include the study prepared by the Italian Trust Fund (Search I, II, 2014), which examined the school environment and responsibility for the health of children in selected European countries, and the study "Heating with Biomass: A Feasibility Study of Wisconsin Schools Heated with Wood" (P Squared Group, LLC 2008).

This study may contribute to closing the gap in knowledge on the examined issue and enriching the theoretical discussion on benchmarking in public administration. Theoretical conclusions and recommendations may be used for a more effective implementation of public policies within the surveyed countries.

\section{Research framework and research foundations}

The efficiency of heating costs of school facilities in the surveyed countries is affected by numerous factors and conditions. Of these the following factors are examined in detail within the present study: functionality of the public administration, impact of the role of local governments (efficiency) on the running of school facilities, existence of an effective energy policy and its impact on the energy operation of school facilities, conduct of an efficient energy audit, implementation of investments in energy-saving programmes, type of used heating media and impact of the natural factor (climate and weather) on the energy operation of school facilities.

It is evident that we deal with a complex set of factors and conditions. The analysis of their impact on the energy costs of school facilities requires finding an adequate theoretical framework in order to carry out the research. The contemporary theory, however, does not offer such a comprehensive framework. There are no studies available that would directly address the given issue. However, within the theory it is possible to find ideas that may be used for the design of a suitable theoretical research framework.

To create the theoretical framework, we adopt the idea of fiscal federalism as offered by Oates (1972, 1977,1999), Tiebout (1956), Musgrave and Musgrave (1989) and Baldwin and Wyplosz (2004), interconnected with the idea of achieving savings in the public sector (Gaebler 1971; Matějová et al. 2014; Půček and Ochrana 2014) and the idea of an efficient allocation of resources (Půček, 2014; Nemec et al. 2014).

The operation of the educational facilities of public schools represents an element of the system of public administration. It may therefore be assumed that the more effective the system of public administration becomes, the more effective the energy management of educational facilities shall be and thus the higher the savings in the public sector that can be achieved.

Allocation efficiency is dependent upon diversity and local information advantage (Špaček, 2014), economies of scale, externalities, control mechanisms (Merickova et al.2012) and fiscal horizontal competition (Baldwin and Wyplosz 
2004). By diversity we mean a diversity of preferences in provided goods within the given region. If the diversity of preferences within provided public goods is high in individual regions, it is preferable to provide the individual goods in a decentralised manner. In case the diversity of consumer preferences in public goods/services is low, it is more efficient to adopt a centralised provision of the given public goods. This conclusion follows from Oates's decentralisation theorem (Oates 1977).

Within centralised decision-making on the provision of public goods, losses may arise that are affected by the volume of demand in individual fiscal units (the more the demand of individual regions gets closer to the "average" central demand, the smaller the losses are) and the price elasticity of the demand (with an increasing inelasticity of demand for public goods losses grow due to the central decisionmaking on the provision of public goods).

Baldwin and Wyplosz $(2004,78)$ note in this respect that the central government may decide that for different individual lower levels (regions) it will provide different volumes of public goods. The problem is that such a decision requires incurring additional costs related to determining local preferences. In comparison, the local government holds an advantage in that it has relatively sufficient information to provide the necessary goods at lower costs. On the other hand, within centrally provided public goods an effect of economies of scale comes to play.

Therefore it is safe to assume that the different organisational structures of public administration in the compared (surveyed) countries will affect the costs of kindergarten, primary and secondary schools (or, in our case, the cost of decentralised/centralised provision of heating, respectively). Will the centralised (or possibly combined) model of public administration report lower heating costs for schools compared to the decentralised model, or will the situation be vice versa?

It follows from Oates's theorem (Oates 1977) that in centralised decisionmaking the provision of public goods leads to a loss of welfare for local consumers of public goods. However, due to the economies of scale lower marginal costs are achieved associated with their provision. Therefore, when deciding upon a centralised/decentralised provision of public goods, authorities of public administration should take into account:

a) The case when losses of the benefit (welfare) are higher than economies of scale; in such a case it is appropriate to provide the given good in a decentralised manner (i.e. to operate the provision of heating of school facilities decentrally),

b) Provided economies of scale outweigh the loss of the effect of a decentralised provision of given goods, it is advisable to provide the given good centrally (i.e. to operate the provision of heating of school facilities centrally).

The decentralised model of fiscal federalism is thus characterised by a high degree of diversification of user preferences, while the centralised model shows a low degree of diversification of user preferences. 
Within the search for a suitable model of public administration for an effective energy management of schools and in the search for factors affecting the efficiency of the energy policy of educational facilities on the level of municipalities of the surveyed countries, we formulate the following hypotheses $(\mathrm{H})$ :

H1: the energy management of educational facilities is more efficient in those surveyed countries that to a greater extent delegate the authority over the operation of educational facilities to the level of local governments when compared to the countries in which the system of public administration is more centralised. $^{6}$

H2: countries that have a central energy policy, and its implementation is delegated to the level of local governments, perform better in the domain of the energy management of educational facilities.

H3: countries that have a central government document (strategy) for the realm of energy policy and have effective implementation tools for their execution achieve better results in the energy management of school facilities.

H4: a tendency may be tracked down that the higher the degree of implementation of the energy audit, the more effective are the austerity measures that are adopted in the domain of operating costs of school facilities.

H5: the selection of the heating medium probably has a higher impact on the growth dynamics of the heating cost of school facilities than the average annual temperature.

\subsection{Analysis of baseline conditions in the compared countries}

How much energy is needed for the operation of school facilities is dependent upon numerous factors and conditions. Of these, the most important ones are the way the public administration is run and the role of local governments in the operation of school facilities, responsibility for the formulation and implementation of energy policy, resources for funding the energy operation of school facilities, use of resources for the strategic planning of energy policy, use and scope of the energy audit, implementation of investments in energy-saving investment programmes as well as the exogenous (impossible to influence) climate factor. Table 2 provides a summarising comparison of the baseline conditions.

For the purpose of comparing the individual countries, we adopted selected relevant factors and conditions that affect the financing of school facilities and the efficiency of energy policies. Individual countries have certain similar characteristics (e.g. a still prevailing centralised system of public administration, a lack of funding resources) but at the same time in other aspects they differ. Apart from

6 In the case of the surveyed countries, the necessary precondition for this operation is the fact that municipalities receive a portion of the funding for the operation of educational facilities from the central budget. 


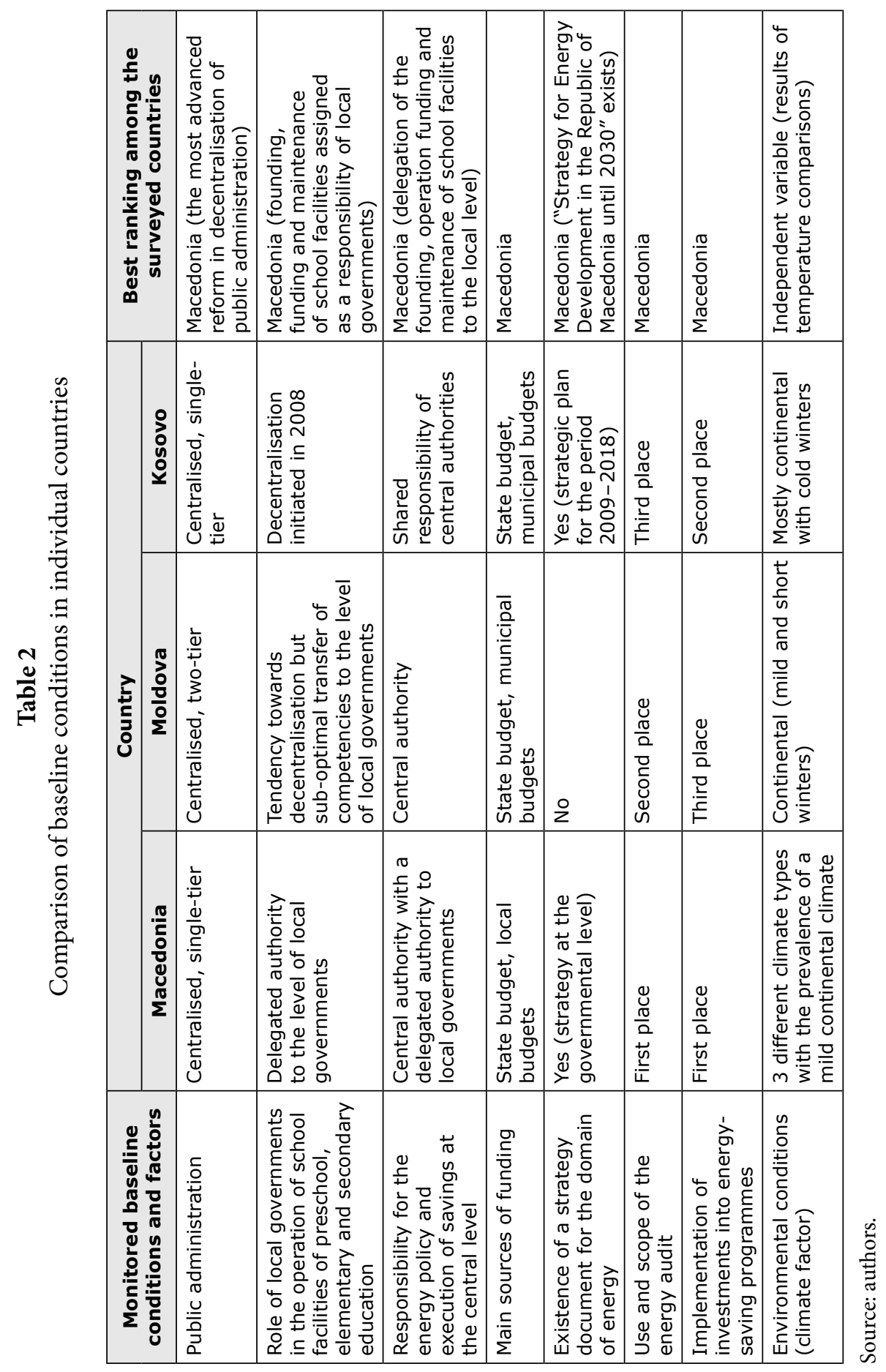


the exogenous factor of weather there are also other dissimilarities in which we may on the basis of the method of comparison find differences and determine the country with the best initial position for the studied domain. Detailed results of the comparison of the individual countries and empirical data for the verification of hypotheses are shown within the following analysis.

\section{Macedonia}

Macedonia may be perceived as a developing country with a single-tier public administration consisting of central authorities and 84 municipalities. The responsibility for energy policy at the central level lie with the Ministry of Finance, Ministry of Economy, Ministry of Environment and Physical Planning, Ministry of Agriculture, Forestry and Water Economy, Ministry of Transport and Communications and, obviously, at the municipal level with the local governments. One of the main objectives of the reform efforts is a gradual decentralisation. In the context of these reforms, the founding, funding, operation and maintenance of school facilities has been delegated to the responsibility of local governments (Zahradník and Koppitz 2012).

The main source of funding is Education-Earmarked, which makes up about $68 \%$ of the budget, local fees ( $22 \%$ of the budget), and VAT ( $5 \%$ of the budget). Marginal sources of funding are capital income, unconditional transfers and others (Zahradník and Koppitz 2012).

Within the domain of energy saving Macedonia has adopted the document "Strategy for Energy Development in the Republic of Macedonia until 2030", whose main objective it is to increase efficiency in energy management, to reduce the total energy consumption in the country and to look for ways of financing energy-saving projects. The main challenges in the domain of energy policy of municipalities include: lack of data, lack of funding needed for the implementation of necessary projects (may be seen as the biggest problem), limited access of local governments to the central-government funds, complicated access to international capital, institutional environment, lack of awareness on the part of the general public and responsible representatives on energy issues, problems with public procurement and accounting for generated savings (Zahradník et al. 2013a).

\section{Moldova}

Moldova ranks among developing countries with a two-tier public administration. The first tier consists of municipalities and towns, and the second tier comprises district authorities and the cities of Chisinau and Balti. A special status is held by the Gagauzia region. At the central level the responsibility for the energy policy lies with the Ministries of Finance, Economy, Environment, Internal Affairs, Construction and Regional Development, and Agriculture and Food Industry. As Macedonia is presently undertaking a public-administration reform whose main objective is decentralisation. The Competences of local governments and regions are not opti- 
mally distributed within the context of education funding and implementation of public policies related to energy savings. Due to the low economic performance of the country, they are not optimally funded, either. State budgetary funds, through which the state allocates towards education annually 5-6\% of GDP, represent the main source of education financing. The cost of maintaining facilities of preschool, elementary and secondary education are covered from the budget of municipalities. Also covered from the budget of municipalities are the salaries of teachers, while transfers from the region add resources to the budget (Zahradník and Koppitz 2012).

The largest share of local school funding is covered by earmarked transfers (47\%), Education Earmarked (17\%), local fees (14\%), capital income (7\%), administration fees (4\%), unconditional transfers (4\%) and others. Compared to other surveyed countries, Moldova has the most centralised system of education funding. It can be seen that in comparison to Macedonia and Kosovo, a redistribution through VAT is missing (Zahradník et al. 2013a).

Expenditures on energy supplies represent $30 \%$ of GDP in Moldova. Energy infrastructure is severely undercapitalised. $60 \%$ of the equipment is over 30 years old and $30 \%$ of the equipment is over 40 years old. In 2007 an energy strategy valid until 2020 was approved which aims to tackle the complex situation of the state energy management. The strategy specifies the main objectives of the industry, key players, assigns responsibilities and identifies sources of funding. The main challenges within the energy management include severe under-financing of the sector, lack of financial resources for reconstructing the facilities provided by the central government to municipalities and regions, lack of attention given to this issue by responsible officials and politicians, and an insufficient use of calculations and methods for the quantification of results of implemented cost-cutting programmes within energy-saving programmes.

\section{Kosovo}

Like the rest of the surveyed countries, Kosovo ranks among developing countries. Public administration in Kosovo is single-tier, composed of 37 municipalities. The responsibility for the energy policy and the execution of savings is shared by the following entities: Ministry of Finance, Economics Development, Environment and Spatial Planning, Local Government Administration and Agriculture, Forestry and Rural Development. In 2008 the main phase of decentralisation had started in Kosovo, based on the Act on Local Self Government and the Act on Local Government Finance. Competences in the areas of sustainable economic development, urban planning, environmental protection, provision of public goods and services, including social services, fire and emergency services were transferred onto municipalities. 
The major share of the contribution towards the financing of local education is taken up by Education Earmarked (44\%), local fees (27\%), earmarked transfers $(12 \%)$, unconditional transfers (8\%), other than national transfers (5\%), and capital income $(4 \%)$. The main strategic document in this area is the "Energy Strategy for the Republic of Kosovo for the Period of 2009-2018" whose main objective it is to strengthen the infrastructure for energy supplies, increase the energy efficiency and the use of renewable resources. Another important document is the "National Energy Efficiency Action Plan" whose main objective it is to reduce the energy consumption by $9 \%$ within 2018 compared to the average for the period 2003-2007 (Zahradník et al. 2013a). With respect to the given issue, Kosovo will have to find a solution to the following problems: lack of funding for running self-governing administrations, non-transparent co-financing on the part of the central government, implementation of energy concepts at the municipal level, raising awareness for the issues with responsible politicians and bureaucrats, introduction of systems for the capture and analysis of energy savings, design of central incentive programmes for municipalities, and raising awareness for the issue among the general public. The following section introduces data collection and results of the empirical analysis.

\section{Adopted methods and data collection}

To compare the individual countries we use a combination of the methods of qualitative and quantitative analysis while the method of benchmarking is key. By benchmarking we understand a systematic, continuous and planned process performed in order to measure, compare and assess processes, products, services or performance parameters with selected organisations, partners or competitors that within selected parameters may be considered better, in order to specify opportunities for self improvement (Nenadál et al. 2011, 15). . Camp defines benchmarking as follows: "a proactive process for the structured change in processes with the aim to achieve a better performance. The benefit of benchmarking is that a company focuses on the best practice in its field and subsequently implements it into its processes. Benchmarking leads to higher profitability, increased asset utilisation, meeting the needs of customers and achieving a competitive advantage." (Magd and Curry 2003, 168). Benchmarking in the public sector has a use in the objective examination of procedures, methods and systems in ensuring the production of public goods and services, funded either partially or fully from public sources (e.g. Nemec et al. 2008). This method also assists to evaluate the quality of publicly provided services, especially in environments where no quality standards are set (e.g. Meričková et al. 2009).

7 Nenadál et al. in their book Benchmarking, Myths and Reality also give definitions of the American Productivity and Quality Center (APQC) and the American Society for Quality (ASQ) by the same author who, in turn, cites the research by Metin Kozak. The vast majority of definitions emphasises a connection with performance-improvement processes. 
Several expert studies deal with an analysis of the specific experience of individual countries with benchmarking. Kuhlmann and Jäkel (2013) deal with comparing the experience with benchmarking of local governments in Sweden, England, Germany and Switzerland. Other comparative studies are, for example, Kuhlmann and Fedele (2010), Hammerschmid et al. 2013 and Nemec et al. (2011). Current studies (Kuhlmann and Jäkel 2013) argue that dominant influence is mainly exerted by institutional factors, specifically the state system, the degree of decentralisation and fiscal autonomy, the size of administrative units and the degree of regional fragmentation. The type of democracy and the culture of bureaucracy may as a whole be marked as initial conditions that affect the character and success of the implementation of individual quality-management tools. For an explicit explanation of individual factors it is necessary to put them in the context of the current knowledge of the school of public choice.

In this study, we adopt the method of benchmarking to explore three domains within the surveyed countries:

- Comparison of management (high-level comparison) - comparison of approaches towards setting the organisational strategy and management, e.g. strategic benchmarking

- Comparison of performance - comparison of the performance of an organisation that uses quantitative indicators with other organisations (the most common indicators include costs, productivity, level of resource utilisation, quality)

- Comparison of processes - comparison and analysis of processes using quantitative and qualitative data and their subsequent redesign in order to improve the performance (Meričková et al. 2009).

\subsection{Data collection}

Data for benchmarking analysis were secured via data collection using a questionnaire. The questionnaire was distributed in either online or paper form to four municipalities in each of the surveyed countries. The municipalities were addressed using the following structure:

1 municipality with more than 100,000 inhabitants

1 municipality with more than 50,000 but less than 100,000 inhabitants

1 municipality with more than 20,000 but less than 50,000 inhabitants

1 municipality with more than 15,000 but less than 20,000 inhabitants

Each municipality will then invite 6 selected schools (if possible, i.e. 2 kindergartens, 2 primary and 2 secondary schools administered by the municipality) to participate in the data collection. The schools shall be selected as an "average" sample with regards to energy use, number of pupils/students, energy costs etc. In addition, available key national data will be evaluated for the overall picture. In 
order to see the trends over a period, whenever relevant, data will be collected for the years 2009, 2010 and 2011.

A more detailed description of the sample is as follows:

Macedonia: Veles, Kumanovo, Gostivar. Total of 8 kindergartens, 35 primary schools and 12 secondary schools have been approached within the sample.

Kosovo: Obiliq, Gjilan, Istog. Total of 15 kindergartens, 89 primary schools and 12 secondary schools have been approached within the sample.

Moldova: Soroca, Edinet, Cimişlia, Primaria OR. Cahul. Total of 29 kindergartens, 6 primary schools and 22 secondary schools have been approached within the sample.

The set of ca. 30 questions have been divided into 4 thematic sub-sets:

1. energy efficiency and investment - ca. $30 \%$ of the questions for municipalities and schools;

2. economic/fiscal - ca. $40 \%$ of the questions;

3. management and public procurement - ca. $20 \%$ of the questions;

4. incentives and disincentives $-10 \%$ of the questions.

Response rate:

Out of 85 questionnaires sent out to the respondents, 10 have been filled out on the municipal level and 37 have been filled out on the school level. Since not all questions have been answered properly, the aggregation of some data is based on smaller samples. An additional manual has been provided by MEPCO to the respondents in order to make the data collection more effective. Although the structure of the sample is not statistically significant, we can assume that the results will give us a fairly accurate description of the situation in individual countries.

\subsection{Benchmarking comparison of individual countries}

Within the first part of benchmarking the key performance indicators were determined. The indicators were split into three levels: 1) indicators at the level of schools, 2 ) indicators at the level of municipalities and 3) indicators at the level of countries.

Indicators were also split into key and supplementary according to their importance. At the level of schools, we may label the following as the key indicators: consumption of heat per student $(\mathrm{kWh} /$ student/year) and heating costs at the school per student (local currency/student/year). Supplementary indicators at the level of schools are as follows: heat consumption at the school per $\mathrm{m}^{2}\left(\mathrm{kWh} / \mathrm{m}^{2} /\right.$ year $)$ and heating costs at the school per $\mathrm{m}^{2}$ (local currency/student/year). 
At the level of municipalities the key indicators were set as follows: heat consumption at all schools per student $(\mathrm{kWh} /$ student/year), heat and electricity costs at all schools per student (local currency/student/year), share of the city budget related to the school operating expenses, share of expenses for energy costs at all schools as part of the total budget of one municipality (per country), energy management index (i.e. energy manager, energy-related strategic document, organising of awareness campaigns, shared purchases of energy, projects at schools). Supplementary indicators were as follows: heat consumption at all schools per $\mathrm{m}^{2}\left(\mathrm{kWh} / \mathrm{m}^{2} /\right.$ year $)$, heating costs at all schools per $\mathrm{m}^{2}$ (local currency $/ \mathrm{m}^{2} /$ year), financial support from the municipal budget (in addition to transfers or grants the municipalities receive from the national budget) for energy costs (local currency/student/year), share of transfers or grants from the central government to municipalities or schools allocated for energy costs (Zahradník et al. 2013b).

\section{Results}

The following section presents the main results of the comparison that may have implications for the analysis and implementation of selected public policies. Among the basic initial conditions may be classified the characteristic of a climate in the individual countries.

Among the individual countries, there are differences in temperature conditions which in turn have an impact on energy consumption. The climate of the Republic of Moldova is temperate continental. Winters are mild and short, summers are hot and long. The average annual air temperature throughout the territory of the Republic of Moldova is above zero $\left(+8^{\circ} \mathrm{C}\right.$ in the north, $+9^{\circ} \mathrm{C}$ in the central parts of the country and $+10^{\circ} \mathrm{C}$ in the south). The length of the heating season is 158 days in the south, 167 days in the central parts (around Chisinau) and 177 days in the north of the country. The climate of Kosovo is predominantly continental, resulting in warm summers and cold winters with Mediterranean and Alpine influences (average temperature within the country ranges from $+30{ }^{\circ} \mathrm{C}$ (summer) to $-10^{\circ} \mathrm{C}$ (winter)). However, due to unequal elevations in certain parts of the country, there are differences in temperature. The Republic of Macedonia is characterised by three different climates: changed Mediterranean, Mountainous, and mildly Continental. The mildly continental climate is most characteristic of the Republic of Macedonia, since it covers the biggest area of the country. It is characterised by relatively cold and humid winters and warm and dry summers. The spring is colder than the fall (Zahradník et al. 2013b).

Apart from the impact of a climate, there is no doubt that a linear relationship exists between the energy consumption and the size of the heated floor area. The consumption (respectively energy savings) of school heating is also affected by investments in strategic austerity programmes, both in their total volume and in their 
relative size, i.e. recalculated per school. Research findings related to these factors that affect the heating energy consumption of schools are shown in the following Table 3.

Table 3

Factors affecting the heating energy consumption of schools in individual countries

\begin{tabular}{|l|c|c|c|}
\hline \multicolumn{1}{|c|}{ Factor } & \multicolumn{2}{c|}{ Country } \\
\cline { 2 - 4 } & Macedonia & Kosovo & Moldova \\
\hline $\begin{array}{l}\text { Average heating floor per student in the } \\
\text { municipality (m })^{2}\end{array}$ & 5.3 & 3.5 & 9.8 \\
\hline $\begin{array}{l}\text { Volume of investments in strategic austerity } \\
\text { programmes in the given country per } \\
\text { municipality (EUR) - year 2009 }\end{array}$ & 86,506 & 108,500 & 957 \\
\hline $\begin{array}{l}\text { Volume of investments in strategic austerity } \\
\text { programmes in the given country per } \\
\text { municipality (EUR) - year 2010 }\end{array}$ & 190,492 & 165,000 & 54,304 \\
\hline $\begin{array}{l}\text { Volume of investments in strategic austerity } \\
\text { programmes in the given country per } \\
\text { municipality (EUR) - year 2011 }\end{array}$ & 141,301 & 65,000 & 0 \\
\hline $\begin{array}{l}\text { Investments in energy-saving projects } \\
\text { (average 2009-2011) recalculated per school }\end{array}$ & 3,768 & 2,768 & 1,416 \\
\hline
\end{tabular}

Source: authors.

The analysis points towards a relatively inefficient use of heated floor area per student in Moldova. We may therefore conclude that school buildings are unnecessarily oversized in this country. Kosovo takes the best ranking. With regard to the factor of the volume of investments in energy-saving programmes, the analysis shows that investments peaked for all countries in 2010, following which the volume of investments has declined. The most resources were allocated to energy-saving programmes by Macedonia. In contrast, Moldova reported a very small volume of investments.

These results are also confirmed by a recalculation to the level of individual schools. The dominant share of projects represented façade insulations, replacements of windows and heating-system replacements. For a higher efficiency of these investments an energy audit of the given school should precede each investment. An energy audit is implemented in $100 \%$ of cases in Macedonia. Contrariwise, in Kosovo an energy audit was performed only in $12 \%$ of schools and the situation is even worse in Moldova, where the audit was performed only in $2 \%$ of schools. We can therefore conclude that in these two countries, the focus of investments is not fully effective, and the undertaken allocations rather represent compensation due to poor technical conditions. 
The energy management index, which assesses the level of energy management in individual countries, describes the situation in the realm of energy management in more detail. The index assesses whether municipalities have established the post of an energy manager, designed strategic documents, organised information campaigns on the possibilities of savings in energy consumption, implemented shared purchases of energy and also whether there are energy-saving projects implemented at schools, where they represent a significant room for savings. The incidence of each factor has a weight of $20 \%$, with the exception of schools, for which the number of implemented projects is assessed. Provided no projects are implement at schools, they receive $0 \%$, in case they implement $1-3$ projects they are awarded a rating of $10 \%$, and if they implement more than 3 projects the corresponding assessment is $20 \%$ (Zahradník et al. 2013b).

The following chart represents the overall results of the energy management index in individual countries and also the results of an assessment in individual categories.

\section{Chart 1}

Results of the energy management index

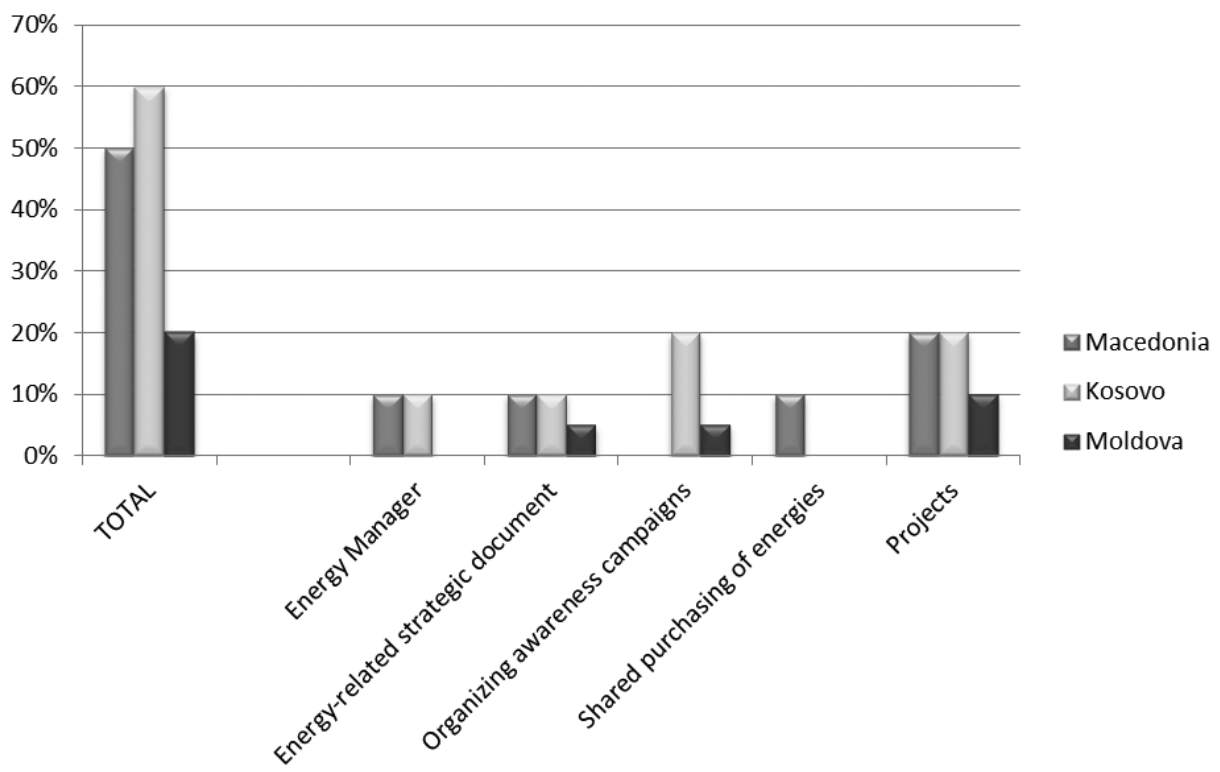

Source: Zahradník et al. (2013b)

The columns represent the total overall assessment of the energy management index. Based on the results, Kosovo received the best score, followed by Macedo- 
nia. Moldova lags greatly behind these two. Kosovo received very high scores when compared to the other nations, mainly due to the awareness campaigns which were organised in this area. The Kosovo results partially contradict the results relating to the implementation of energy audits. Macedonia, the country listed second on the assessment of the energy management index dramatically lags behind other countries in organising awareness campaigns, whereas it is the only one which uses centralised purchasing for energy. Moldova holds the last place in the review, having achieved worse results than the surrounding countries, especially in the category of strategic documents and projects. Items such as the centralised purchasing of power and a tool for creating energy-manager positions are not used in Moldova at all.

Results of the analysis of costs of heating in the surveyed countries point towards unsatisfactory conditions. Heating costs in school facilities (for the period 2009-2011) demonstrate a growing trend (see Table 4).

Table 4

Results of the final comparison of heating costs per $\mathrm{m}^{2}$ (period 2009-2011)

\begin{tabular}{|l|c|c|c|}
\hline \multicolumn{1}{|c|}{ Monitored factor } & Macedonia & Kosovo & Moldova \\
\hline $\begin{array}{l}\text { Average heating cost } 2009 \text { per } \mathrm{m}^{2} \text { of } \\
\text { heated floor }\end{array}$ & EUR 8.9 & EUR 8.2 & EUR 7.8 \\
\hline $\begin{array}{l}\text { Average heating cost } 2010 \text { per } \mathrm{m}^{2} \text { of } \\
\text { heated floor }\end{array}$ & EUR 9.8 & EUR 8.8 & EUR 9.3 \\
\hline $\begin{array}{l}\text { Average heating cost } 2011 \text { per } \mathrm{m}^{2} \text { of } \\
\text { heated floor }\end{array}$ & EUR 12.4 & EUR 9.9 & EUR 10.7 \\
\hline Primary heating source & oil & coal/wood & gas \\
\hline $\begin{array}{l}\text { Average year temperature (in degrees } \\
\text { Celsius) }\end{array}$ & $12^{\circ}$ & $12^{\circ}$ & $10^{\circ}$ \\
\hline
\end{tabular}

Source: authors.

The highest dynamics can be found in the growth in heating costs in Macedonia, where over the period 2009-2011 the costs have increased by $39 \%$, and in Moldova, where the costs have increased by $37 \%$. In Kosovo the increase in costs was comparatively lower. Proposed solutions to the problem are contained within the final section of this paper.

The results of the comparison of individual indicators in the domain of thermal management point towards different rankings of the surveyed countries (see Table 5). 


\section{Table 5}

Results of the comparison of individual indicators

\begin{tabular}{|l|c|c|c|}
\hline \multirow{2}{*}{ Indicator } & \multicolumn{2}{|c|}{ Country and its ranking within the compared indicator } \\
\cline { 2 - 4 } & Macedonia & Moldova & Kosovo \\
\hline $\begin{array}{l}\text { Investments in energy- } \\
\text { saving projects } \\
\text { recalculated per school }\end{array}$ & First place & Third place & Second place \\
\hline $\begin{array}{l}\text { Primary heating source } \\
\text { and its impacts on savings }\end{array}$ & Oil & Gas & Coal/wood \\
\hline $\begin{array}{l}\text { Costs of heating per } \text { m }^{2} \\
\text { (2009-2011) in terms of } \\
\text { growth dynamics }\end{array}$ & Third place & Second place & First place \\
\hline $\begin{array}{l}\text { Average heating floor per } \\
\text { student in the municipality }\end{array}$ & Second place & Third place & First place \\
\hline $\begin{array}{l}\text { Assessment of rate of } \\
\text { investment in energy- } \\
\text { saving programmes in } \\
\text { individual countries }\end{array}$ & First place & Third place & Second place \\
\hline $\begin{array}{l}\text { Average annual } \\
\text { temperature }\end{array}$ & 12 degrees Celsius & 10 degrees Celsius & 12 degrees Celsius \\
\hline
\end{tabular}

Source: authors.

All the surveyed countries share a common characteristic in that there is much room for improvement of the existing conditions, in particular within the area of central purchases of energy, strategic planning and organising awareness campaigns. At the same time, the ranking of individual countries differs. The research results show that over the last three years, Macedonia invested the most resources towards the implementation of energy-saving measures in absolute terms, yet it has a higher growth dynamic in heating costs than Moldova. The country with the lowest rate of growth in costs is Kosovo, which achieves the best scores among the compared countries within an assessment of the energy management index.

The main causes of the growing trend could be sought in the use of obsolete heating technologies and in the type of heating media. In the case of Macedonia, we must also take into account the fact that investments in energy-saving measures bring their effects only within the horizon of several years. It is not without interest that each of the surveyed countries uses a different dominant heating medium. According to the World Bank study carried out in Kosovo (Zahradník et al. 2013a), a change of the heating medium may result in savings of up to $25 \%$ of the previous heating costs.

The price development of heating media on the market also has a sizable impact on the total costs. In the case of Moldova the raw material that is predominantly used is natural gas, and the price of this commodity is dependent upon the price of oil (since natural gas is used as its substitute) as well as upon the development of 
the exchange rate of a domestic currency against USD. Over the period 2009-2011, there was a drop in the price of gas in the first half of 2009 followed by a growth which peaked in early 2010. From then, the trend of natural gas prices declined until the end of 2011. Contrariwise, an opposite trend may be observed in the case of prices of heating oil as they steadily grew over the period 2009-2011. The same trend also followed the price of coal, which is used as the heating medium in Macedonia. When assessing the costs of heating media, it cannot be abstracted from the level of frontloading and commodity prices at which the stock was purchased, price development of substitutes and complements of individual commodities and the development of the exchange rate of a domestic currency to USD. Equally important is the structure and degree of the state regulation of energy markets in individual countries.

The volume of energy consumption and thus also its price is also affected by the weather in the individual countries. When we compare average temperatures, Kosovo and Macedonia enjoy more favourable initial conditions with an average temperature of 12 degrees Celsius, while in Moldova the average temperature is two degrees centigrade lower. In Moldova the length of the heating season extends up to 177 days.

\subsection{The results of the test hypothesis}

From the perspective of verifying the established hypotheses the following results were reached: hypothesis $\mathrm{H} 1$, which is based on the assumption of the Oates theorem about the positive impact of decentralised decision-making on the allocation efficiency, was confirmed. Macedonia, which has advanced the furthest from the surveyed countries in its decentralisation of public administration, also has a more efficient energy policy and achieves the best results in its implementation of energy-saving measures. Delegating the responsibility for maintenance of school facilities onto local governments has a positive impact on the resulting energy management index.

Also confirmed was hypothesis $\mathrm{H} 2$, which holds that "countries that have a central energy policy and delegate its implementation onto local governments perform better in the department of energy management of school facilities." Macedonia and Kosovo both are countries that have a central energy policy while actors from the level of local governments co-operate on its implementation. Both countries achieve better results compared to Moldova, reflected especially within the domain of investments in energy-saving projects recalculated to the per-school data and also in results of the energy management index. This confirms the theoretical assumption that the efficiency of allocation is dependent upon diversity and local information advantage, control mechanisms, fiscal horizontal competition and activities of actors responsible for the implementation of energy policy. 
Also hypothesis $\mathrm{H} 3$ was confirmed. Countries that have a central government document (strategy) for energy policies and effective implementation tools for its execution achieve better results in the energy management of school facilities. Macedonia and Kosovo both have a long-term strategy for energy policy and also achieve the best future-oriented results in the domain of a volume of investments in energy-saving programmes.

Hypothesis $\mathrm{H} 4$ was also verified, claiming that the higher the degree of the energy-audit implementation, the more effective are the austerity measures that are adopted within the operating costs of school facilities. Thus the "theory of savings within the public sector" was confirmed (Půček and Ochrana 2014) in that the efficiency of investments is higher within the public sector when preceded by an audit. In the case of Macedonia, which scores the best results in the volume of investments in energy-saving programmes, an energy audit is carried out in $100 \%$ of cases. On the contrary, in Moldova, which carries out an energy audit to a very limited extent (only $2 \%$ of cases), investments are used as a means of rehabilitation of the poor technical condition and not as a tool to support a systemic change in the energy economy of school facilities. Also in this case the negative impact of the lack of a strategic document for the energy sector shows.

Hypothesis $\mathrm{H} 5$, which focuses on the role of choosing the heating medium and its impact on the heating of school facilities was confirmed only partially. To verify the claim that the choice of heating medium probably has a higher impact on the growth of heating costs of school facilities than the average annual temperature, no sufficiently long time series of data was available (only the period 2009-2011). It turns out that Macedonia - which, compared to Moldova, has relatively higher average annual temperatures and uses a more expensive heating medium (oil) compared to Moldova, which in turn uses gas - has the highest growth rate in heating costs of school facilities. The effectiveness of the measures in the domain of energy policy and the resulting savings are thus significantly impacted by exogenous factors related to the openness of an economy and the dependency of small open economies on the behaviour of key players on the energy-resource markets.

\section{Discussion and Recommendations}

From the results of the study it is clear that the most room for improvement regarding the achievement of savings exists in Moldova, mainly through a more efficient use of the heated-floor area and an introduction of energy audits prior to the implementation of investments in energy-saving measures. Moldova is also characterised by a very low level of investments in energy-savings measures.

For all the surveyed countries the rising trend in costs of heating school buildings is characteristic. The absolute cost differences may be caused mainly by the differences in the use of a primary heating media, market structure and the degree 
of regulation in individual countries. Their identification at the level of local governments may be another factor that may contribute towards an increase in the cost-effectiveness of heating school facilities in surveyed countries.

As the first step it is therefore necessary to specify the appropriate funds and to establish conditions for the financing of energy-saving projects. Presently a centralised form of fiscal federalism prevails in Moldova, Kosovo and Macedonia. Municipalities are thus dependent upon grants and subsidies from the central government. A possible solution is increasing the share of municipalities on the redistribution of revenues from shared taxes, particularly VAT, in order to finance local schools. Also the possibility comes forward of using data on the number of pupils/students as the redistribution criterion for allocation of tax revenues. The theme of fiscal federalism deals with the following studies: Palermo (2013), Aristovnik (2012) and Bartlett (2013). The decentralisation of the provision of certain public goods and services at the municipal level (Gellén, 2013) is related to the change of fiscal federalism. The effects of such measures across Europe have relatively extensive empirical evidence, e.g. general (Ágh, 2010), pre-school education (Montén and Thater 2011, Matějová et al. 2014), water (Picazo - Tadeo, et al. 2009, Byrnes et al. 2010), hospitals (Blank and Valdmanis 2010), public libraries (De Witte and Geys 2009) and public transportation (Walter and Cullmann 2008).

For the implementation of austerity projects the adoption of the concept of public procurement, PPP projects and EPC (Energy Performance Contracting) could be considered. The utilisation of these tools, however, is also associated with significant risks (Lee et al. 2015, Deng et al. 2015, Nail et al. 2004).

To ensure the continuous improvement of the entire energy management system, there should be a continuation with further benchmarking cycles. The energy management index revealed some heterogeneity among the energy management systems in the countries examined, and therefore, the scope for implementing a benchmarking cycle is surveyed among the countries. The positive benefits of benchmarking for continuous improvement have been confirmed by several empirical studies in the nations of Central and Eastern Europe, for example Placek et al. 2014, Nemec et al. 2008, Vancauwenberghe et al. 2011).

Although the study only compares three countries, we believe that the findings enrich the scientific discussion among researchers who deal with problems of local economies. The analysis of the factors affecting the cost of heating educational institutions can produce recommendations for further research and an examination of factors that influence the effectiveness of local public finances and contribute to the theoretical discussion of benchmarking in public administration. 


\section{Conclusion}

The research findings show that school buildings make up the largest share in the total number of buildings owned by municipalities and therefore represent the greatest potential for achieving energy savings. The analysed performance benchmarking represents the first step towards austerity measures in the domain of energy savings in education for municipalities of Macedonia, Kosovo and Moldova. The results of the analysis revealed considerable room for improvement in all the participating countries.

The surveyed countries are characterised by an obsoleteness and under-funding of energy capacities. All the countries are officially characterised by a low level of municipal indebtedness. However, this comes with the cost of a high hidden debt due to the lack of investments into the local infrastructure.

Recommendations to achieve the desired savings in energy management are based on a gradual decentralisation model of fiscal federalism and the associated decentralisation of public services and goods towards the level of municipalities. For an increase in the efficiency of allocating public funds for investment in energysaving measures, it is appropriate to adopt the PPP projects and EPC (Energy Performance Contracting). To achieve continuous improvement, it is appropriate to continue benchmarking cycles. The implementation of these recommendations can contribute to the effective implementation of local public policies.

\section{Acknowledgements}

This article has been elaborated as one of the findings of research project P-17 "Science of a society, politics and media within challenges of the time" by the Faculty of Social Sciences, Charles University in Prague and VGS 2014K01 "Analýza vztahů a vazeb mezi podniky, zákazníky, veřejnou správou a občany (Rozhodování podniků, zákazníků, samosprávy a dalších subjektů)"

\section{References}

Ágh, A. 2010. "Europeanization and Democratization in ECE: Towards the Multilevel and Multiactor Governance." The NISPAcee Journal of Public Administration and Policy.3 (1). 7-59.

Aristovnik, A. 2012. "Fiscal Decentralization in Eastern Europe: Trends and Selected Issues." Transylvanian Review of Administrative Sciences 37E, 5-22.

Baldwin, R. and C. Wyplosz. 2004. The Economics of European Integration. Maidenhead: McGraw-Hill. 
Bartlett, W. P. 2013. Decentralisation and Local Development in South East Europe. Basingstoke, Hampshire: Palgrave Macmillan.

Blank, J. L. and V. G. Valdmanis. 2010. "Environmental Factors and Productivity on Dutch Hospitals: A Semi-Parametric Approach.” Health Care Management Science 13(1), 27-34.

Byrnes, J., L. Crase, B. Dollery and R. Villano. 2010. “The Relative Economic Efficiency of Urban Water Utilities in Regional New South Wales and Victoria." Resource and Energy Economics 32(3), 439-455.

Deng, Q., X. Jiang, Q. Cui and L. Zhang. 2015. "Strategic Design of Cost Savings Guarantee in Energy Performance Contracting under Uncertainty." Applied Energy, 13968-80. doi:10.1016/j.apenergy.2014.11.027.

De Witte, K. and Geys, B., 2012. "Citizen coproduction and efficient public good provision: Theory and evidence from local public libraries," Discussion $\mathrm{Pa}$ pers, Research Professorship \& Project “The Future of Fiscal Federalism” SP II 2012-108, Social Science Research Center Berlin (WZB).

Gaebler, L. R. 1971. "Population Size as a Determinant of City Expenditures and Employment: Some Further Evidence.” Land Economics 47(2), 130-138.

Gellén, M. 2012. "Does Centralization Serve Efficiency? De-Agencification in Hungary." The NISPAcee Journal of Public Administration and Policy.5 (2). 67-87.

Hammerschmid, G., S. Van de Walle and V. Stimac. 2013. "Internal and External Use of Performance Information in Public Organizations: Results from International Survey." Public Money \& Management 33(4), 261-268.

Kuhlmann, S. and T. Jäkel. 2013. "Competing, Collaborating or Controlling? Comparing Benchmarking in European Local Government.” Public Money \& Management 33(4), 269-276.

Kuhlmann, S. and P. Fedele.2010 "New Public Management in Continental Europe, Local Government Organization in Germany, France and Italy from a Comparative Perspective." In Wollman H. and Marcou G. The Provision of Public Services in Europe. Cheltenham Glos. Edward Edgar Publishing.

Lee, P., P. Lam and W. Lee. 2015. "Risks in Energy Performance Contracting (EPC) Projects." Energy \& Buildings, 92116-127. doi:10.1016/j.enbuild.2015.01.054.

Magd, H. and A. Curry. 2003. "Benchmarking: Achieving Best Value in Public-Sector Organisations.” Benchmarking 10(3), 261-286.

Matějová, L., M. Plaček, M. Křápek, M. Půček and F. Ochrana. 2014. "Economies of Scale: Empirical Evidence from the Czech Republic." In Danuše Nerudova (ed.). Procedia Economics and Finance: $17^{\text {th }}$ International Conference Enterprise and Competitive Environment 2014. $1^{\text {st }}$ edn. Amsterdam: Elsevier Science Bv, 403-411. 
Meričková, B., M. Šumpíková and P. Rousek. 2009. “Benchmarking na úrovni miestnej samosprávy: vybrané problémy" [Benchmarking at the level of local government: Selected issues]. In Květa Kubátová. Teoretické a praktické aspekty veřejných financí [Theoretical and practical aspects of public finance]. Praha: Nakladatelství Oeconomica, 1-15.

Meričková, B., Nemec, J. and Vozárová, Z. 2012. "Management of contracting public services and its quality in Slovakia." The NISPAcee Journal of Public Administration and Policy.5 (1). 55-74.

Montén, A. and C. Thater. 2011. "Determinants of Efficiency in Child-Care Provision." Finanz Archiv: Public Finance Analysis 67(4), 378-403.

Musgrave, R. and P. Musgrave. 1989. Public Finance in Theory and Practice. $5^{\text {th }}$ edn. New York: McGraw-Hill.

Nail, M., D. Anderson and J. Comerford. 2004. "If Energy Performance Contracting Is So Good Why Aren't More Agencies Using It?” Journal of Housing \& Community Development 61(4), 26-30.

Nemec, J., B. Meričková and M. Fantová-Šumpíková. 2011. "Is the Estonian Benchmarking Really Better? The Impacts of Research Methodology on Research Results." Public Management Review 13(4), 539-549.

Nemec, J., B. Meričková and F. Ochrana. 2008. "Introducing Benchmarking in the Czech Republic and Slovakia: Processes, Problems and Lessons." Public Management Review 10(5), 673-684.

Nemec, J., B. Mikušová Meričkováa and M. Grega. 2014. "Contracting, Outsourcing, Procurement: Selected Factors Limiting their Success in the CEE Region." Paper presented at XVIII IRSPM Conference, 9-11 April, Carleton University, Ottawa, Canada.

Nenadál, J., D. Vykydal and P. Halfarová. 2011. Benchmarking mýty a skutečnost [Benchmarking myths and reality]. Praha: Management Press.

Oates, W. E. 1999. "An Essay on Fiscal Federalism." Journal of Economic Literature 37(3), 1120-1149.

Oates, W. E. 1977. “An Economist's Perspective on Fiscal Federalism." In W. E. Oates. The Political Economy of Fiscal Federalism. Lexington, MA: Heath Lexington, 3-30.

Oates, W. E. 1972. Fiscal Federalism. New York: Harcourt Brace Jovanovich.

OECD. 2011. "Education at a Glance." Available at http://www.oecd.org/dataoecd/61/2/48631582.pdf (last accessed September 7, 2014).

Palermo, F. 2013. Regional Dynamics in Central and Eastern Europe: New Approaches to Decentralization. Leiden: Martinus Nijhoff Publishers. 
Picazo-Tadeo, A. J., F. González-Gómez and F. J. Sáez-Fernández. 2009. “Accounting for Operating Environments in Measuring Water Utilities' Managerial Efficiency." The Service Industries Journal 29(6), 761-773.

Plaček, M., Půček, M. and Jetmar, M. 2014. "Collaborative benchmarking of municipalities in the Czech republic: present experience." The NISPAcee Journal of Public Administration and Policy. 7 (1): 63-83.

P Squared Group, LLC. 2008. Heating with Biomass: A Feasibility Study of Wisconsin Schools Heated with Wood. Madison, Wisconsin: P Squared Group LLC and Biomass Energy Resource Center.

Půček, M. 2014. "Vedou vyšší výdaje na úředníka k nižšímu riziku korupce? (Analýza českých krajů)" [Do higher expenditures per official result in lower risk of corruption? (Analysis of Czech regions]. Ekonomický časopis 2(62), 150-166.

Půček, M. and F. Ochrana. 2014. "Theory and Practice of the Public Sector Savings: The Case of Czech Regions." Transylvanian Review of Administrative Sciences 42E, 203-224.

Search I, II. 2014. "School Environment and Respiratory Health of Children (Ministero dell'Ambiente Edellatutela del Territorio e del Mare)." Regional Environmental Center. Available at http://search.rec.org/outcomes/assessment-ofenergy-use/analysis-of-school-hvac-systems.html (last accessed September $7,2014)$.

Špaček, D. 2014."Coordination of and through E-Government: The Case of the Czech Republic." The NISPAcee Journal of Public Administration and Policy.7 (1). 83-106.

Tiebout, M. C. 1956. "A Pure Theory of Local Expenditure." Journal of Political Economy 64, 416-424.

Vancauwenberghe, G., Crompvoets, J. and Bouckaert, G. 2011. "Interorganizational Information Sharing as a Driver of Change in Public Administration." The NISPAcee Journal of Public Administration and Policy.3 (2). 87-106.

Walter, M. and A. Cullmann. 2008. "Potential Gains from Mergers in Local Public Transport: An Efficiency Analysis Applied to Germany." Discussion papers 832. Berlin: German Institute for Economic Research.

Zahradník, P. and D. Koppitz. 2012. The Assessment Paper. Under the assignment of: Transfer of Czech knowledge in support of local government association of Macedonia and Kosovo to strengthen capacities for policy advocacy for improving/establishing fiscal incentives for energy efficiency measures in public schools. Praha: Mepco. 
Zahradník, P., M. Zajíček and D. Koppitz. 2013a. Czech Experience with Financial Support of Energy-Efficient Measures Based on an EU Background as An Inspiration and Recommendation for Macedonia, Moldova and Kosovo. Praha: Mepco.

Zahradník, P., M. Zajičček and D. Koppitz. 2013b. Analyst Report. Within the assignment: Transfer of Czech knowledge in support of local government association of Macedonia and Kosovo to strengthen capacities for policy advocacy for improving/establishing fiscal incentives for energy efficiency measures in public schools. Mepco. Praha. 